\title{
GEORGES SELZOFF, UMA CRÔNICA
}

\section{Denise Bottmann}

\begin{abstract}
Uma crônica bastante simpática na história da tradução literária no Brasil é a da casa publicadora Edição Cultura, de Georges Selzoff, e sua coleção chamada "Bibliotheca de Auctores Russos".

A editora teve trajetória muito efêmera, não chegando a completar dois anos de existência entre 1930 e 1932, e um catálogo restritíssimo: um total de apenas doze títulos. Mas o que há de interessante é que foi ela a responsável pela publicação em livro das primeiras traduções brasileiras, feitas diretamente do original, de obras de alguns importantes autores da literatura russa.
\end{abstract}

\section{Origens do projeto}

Iúri Zéltzov, filho do casal russo Leonid Zéltzov e Catharina Khochlóvkina, nasceu em 8 de abril de 1896 na então Pérsia. Mais tarde, a família se estabeleceu em Riga, na Letônia, onde existiam várias colônias russas. Com formação em química, migrou para o Brasil em algum incerto ano na esteira da Revolução de 1917. Estabeleceu-se em São Paulo, onde, segundo alguns, dedicou-se à profissão de químico ou, segundo outros, entregou-se ao comércio. Ao se radicar no Brasil, Iúri adotou para seu primeiro nome a versão afrancesada de Georges; para o sobrenome que hoje grafamos como Zéltzov, ele adotou a transcrição fonética também francesa de Selzoff. Mais tarde adquiriu cidadania brasileira, recebendo sua naturalização em 1933.

A certa altura da vida, Georges Selzoff decidiu que se dedicaria a divulgar a literatura russa no Brasil. Nossos intelectuais, literatos e leitores em geral já trafegavam naquela época com relativa assiduidade entre os diversos meandros da alma da Mãe Rússia, com seus mujiques, nobres, anarquistas, pacifistas e revolucionários, em meio ao esplendor de São Petersburgo e ao gelo das estepes siberianas - porém em traduções feitas maciçamente a partir do francês, com suas lentes interpretativas muito peculiares. Traduções brasileiras feitas diretamente dos originais russos inexistiam.

Então com 34 anos de idade, Selzoff se sentia em posição especialmente favorável para preencher tal lacuna. Como dizia em "À guisa de introito” (1930), um 
texto revelador que serviu de prefácio aos primeiros lançamentos da casa, ele se alinhava entre as fileiras dos intelectuais; sendo de origens russas, tinha no próprio sangue a língua e a expressão literária da alma russa; no Brasil, constatara o interesse do público leitor e a inexistência de traduções diretas; e assim, agora que "já nos é dado expressar-nos no bello idioma de Camões", quis retribuir "com algumas joias da literatura russa a fidalga hospitalidade" com que, imigrante da grande família russa que se espalhara em “caravana desordenada” pelo mundo após a Revolução de 1917, fora acolhido no Brasil. Para levar a cabo "a tarefa que nos impusemos - traduzir os auctores russos", lançou-se também à ideia de criar uma editora (1930, p. 7-9).

Para dar início a ela, Georges Selzoff firmou sociedade com um F. Olandim e assim, em meados de 1930, nasceu a Edição Cultura, G. Selzoff \& F. Olandim.

A identidade de seu sócio é um mistério: quem era ele? Gostaria de imaginar que fosse talvez Francisco Olandim, naquela época funcionário do Banco Francês e Italiano na sucursal de São Paulo, talvez ainda o mesmo Francisco Olandim amigo de Affonso Schmidt, porém nada me permite afiançá-lo.

De todo modo, o projeto da Edição Cultura era trazer ao Brasil a literatura russa em traduções feitas diretamente do original, e assim a editora foi estruturada tendo como eixo central uma coleção chamada "Bibliotheca de Auctores Russos".

Já em junho de 1930, os rumos pareciam razoavelmente esboçados, como mostra uma mensagem de Guilherme de Almeida, então recém-eleito para a Academia Brasileira de Letras, saudando a nascente editora nos seguintes termos:

Quem quer que se interesse pela nossa cultura, não pode deixar de applaudir, com o mais vivo enthusiasmo a iniciativa altamente intellectual dos Srs. G. Selzoff e F. Olandim, que se propõem traduzir para o portuguez, para a Edição "Cultura", os melhores autores russos, desde Tolstoi até os mais modernos.

É o que faço, com estas palavras, formulando aos editores os mais sinceros votos pelo triumpho completo do seu bello emprehendimento.

Aqui entra um aspecto essencial. Se Selzoff já tinha do "bello idioma de Camões" domínio suficiente para considerar que lhe seria "facil e agradavel" a tarefa de traduzir seus autores de estimação, por algum motivo - na verdade, não muito difícil de adivinhar - decidiu que não arcaria com ela sozinho. Desde o princípio, pareceu-lhe 
indispensável ter um colaborador constante para seu programa de traduções. Como fica claro na mensagem acima, nessa fase inicial o parceiro tradutor era também o sócio editor.

Ainda a mesma mensagem traz um detalhe curioso: "os maiores autores russos, desde Tolstoi até os mais modernos". Fica-se a pensar quais seriam esses autores "mais modernos", pois Tolstói morrera mal fazia vinte anos e, de todos os que vieram a ser publicados pela casa, o único que se poderia incluir entre os modernos (se o critério de modernidade fosse a cronologia) seria Gorki. Uma rasa explicação para esse enigmático comentário de Guilherme de Almeida seria, talvez, que os próprios tradutores-editores ainda não haviam definido muito bem o que iriam publicar - ou, quiçá, alguma desatenção do encomiasta aos nomes desfiados por eles. Outra explicação menos rasa poderia residir na disposição da editora em atender ao mais recente interesse do público pela literatura pós-1917, daí constando Tolstoi como representante magno da velha escola e os "mais modernos" como expressão literária da nova realidade soviética, entre eles destacando-se Gorki.

Se tal fora a intenção de nossa dupla, por que não vieram a realizá-la? E aqui lembra-me um comentário de Rubem Braga, catorze anos depois: ao organizar uma antologia de contos russos, conta ele que se deparou com "um obstáculo intransponível: a falta da grande maioria dos textos" no original (Braga, 2004, p. 9). A disponibilidade não devia ser maior em 1930, o que me faz imaginar que Selzoff dependia basicamente de seu acervo pessoal, talvez não tão atualizado no quesito da modernidade literária que despontava na nova União Soviética. Hipóteses, hipóteses. Mas retornemos ao tema principal.

Pelo visto, então, estava tudo pronto para decolar: havia algum capital, havia excelente material, havia público potencial, havia apoio intelectual e até quem traduzisse as obras diretamente do original. A dinâmica que adotaram nesse sistema de tradução a quatro mãos se manteve até o final da editora: Selzoff traduzia as obras do russo para o português que adquirira e seu colaborador, nesses inícios Olandim, vazava a linguagem em termos e fraseados mais escorreitos. ${ }^{1}$

\footnotetext{
${ }^{1}$ Segundo Boris Schnaiderman (Scarpin, 2010), Selzoff ia lendo e traduzindo o original em voz alta, enquanto o parceiro ia escrevendo em "português aceitável". Em vista de outros indícios que retornarão adiante, tenho por mais provável que Selzoff traduzia por escrito, por conta própria, e seu colaborador trabalhava e polia essa versão inicial (o que, evidentemente, não excluiria um acompanhamento oral nessa segunda fase, para elucidar trechos, dirimir dúvidas etc.).
} 
E assim é que, no segundo semestre de 1930, a Edição Cultura, da sociedade G. Selzoff \& F. Olandim, com sede à Rua Conselheiro Crispiniano, 74, sala 28, no centro de São Paulo, inaugura suas atividades com a Bibliotheca de Auctores Russos.

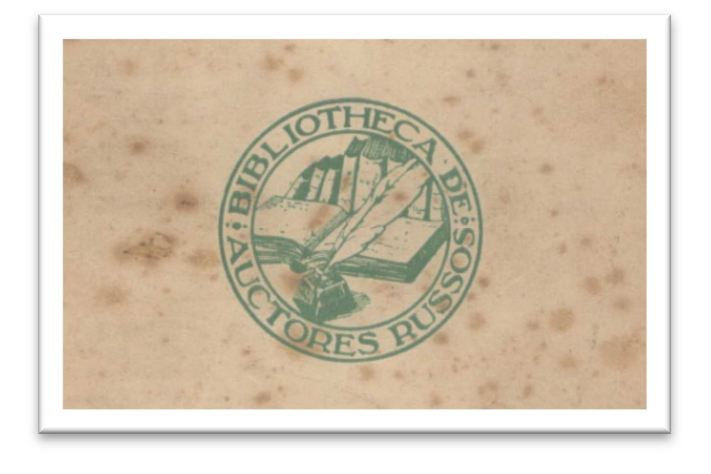

Sinete estampado na página inicial das edições

\section{A primeira fase}

A escolha para o primeiro lançamento da casa recai sobre um "moderno": Maximo Gorki, com uma coletânea de quatro contos enfeixada sob o título de um deles, Konovaloff. ${ }^{2}$ A página que abre o volume traz uma frase de Lucrécio que se manterá como lema da casa até o final: Eripitur persona, manet res (algo como "Arrancada a máscara, a coisa permanece”). Segue-se um interessante prefácio escrito por Selzoff, “À guisa de introito", e a já citada mensagem de Guilherme de Almeida, reproduzida tanto numa coluna em caracteres tipográficos quanto numa página dupla com a caligrafia manuscrita, como se vê abaixo.

\footnotetext{
${ }^{2}$ Sempre que me referir especificamente aos volumes publicados na Bibliotheca de Auctores Russos, manterei a grafia dos autores e títulos usada pela casa.
} 


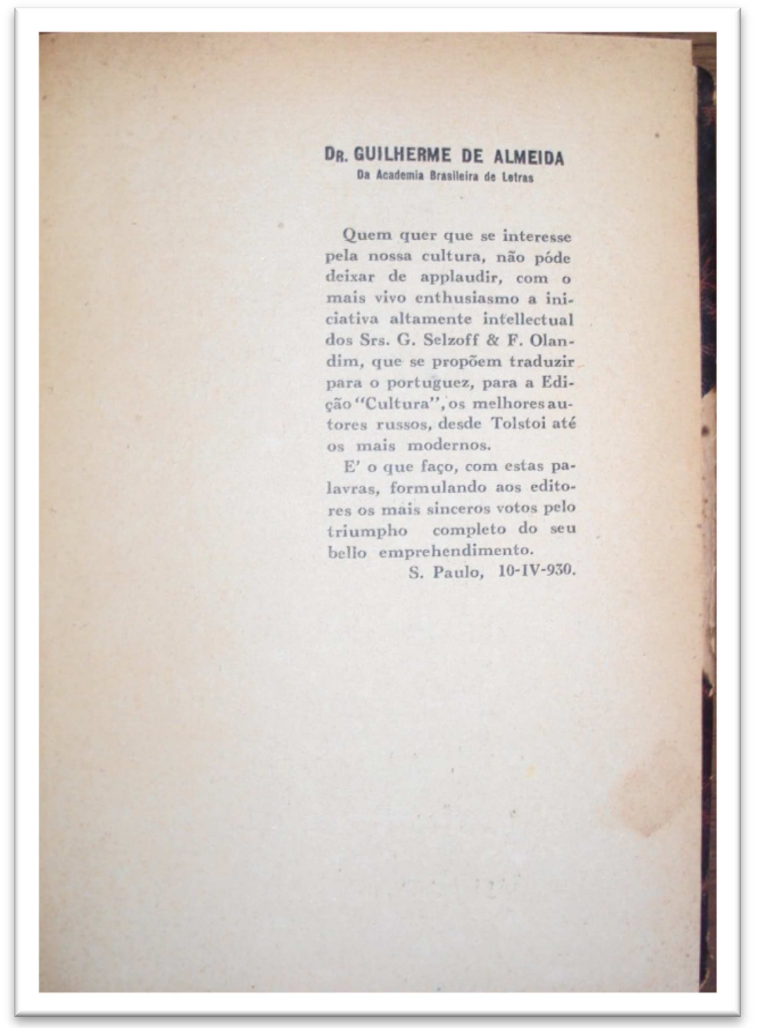

P

nilua quar que al intereng. bele mosuc cultura, Más porde dei- xar de epplaudir, crme o undis vivo reuttsusiasuro a iniciative altamente intellectua dos br. G. Pelfoft \& F. Olemarin, que He pupoem tradutis pare p portuguet, para a Gaicá "Cultwre", os meehores auteres rivios, derde Tolstoi ati os Mris murderuos.
G'o que faco, Cnu estes palavias, formulaudo cos $\ell$. - ditires as mais scruceres votos pelo trimupho Conpleto as ser billo emprehendiurento.

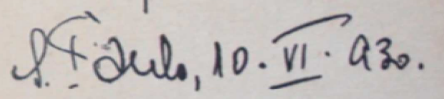

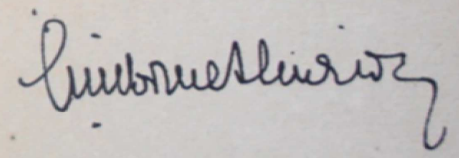

Mensagem de Guilherme de Almeida, in Gorki, Konovaloff (1930, p. 11-13) 
A edição não traz créditos de tradução, mas, como apontado acima, teriam sido Selzoff (atribuindo-a a si só em seu introito) e Olandim, conforme indicado na mensagem de G. Almeida.

Vale mencionar que, quase ao final do introito que abre a edição, Selzoff (1930, p. 9) declara:

É assim que já pusemos, sob uma nova luz, algumas das mais commovedoras novelas de Gorki e trabalhamos, febrilmente, na publicação, para muito breve, de traducções de Ivan Turguenieff, Leonide Andreieff, Alexandre Kuprin e Anton Tchecoff.

A promessa não se cumpriu plenamente, como se verá mais tarde, mas é interessante notar a sensação de urgência que transpira dessas palavras.

Konovaloff teve uma segunda edição em 1931, que calculo ter saído entre fevereiro e maio. Trata-se de uma edição revista, que traz um dado significativo: a "Edição Cultura - G. Selzoff \& F. Olandim" passa a ser apenas "Edição Cultura Georges Selzoff". Todos os demais elementos da primeira edição são mantidos.

O segundo volume lançado pela editora, ainda em 1930, é também uma coletânea, agora de Anton Tchecoff, com nove contos e o título de Os inimigos. Além do introito de Selzoff (agora já eliminado o parágrafo citado acima) e da dupla reprodução da mensagem de Guilherme de Almeida, o volume traz uma prancha com uma foto de Tchecoff, bem como uma introdução à sua vida e obra, escrita por Selzoff, assinando apenas como "S.". Quanto à tradução, aplica-se o mesmo dito acima.

Os inimigos também terá uma segunda edição revista em 1931, talvez até com uma reimpressão posterior. Tal como na reedição de Konovaloff, a sociedade com F. Olandim já está desfeita, constando a Edição Cultura apenas com Georges Selzoff, o qual passa a acrescentar seu nome também na página de rosto, junto com o título da coleção. Podemos situar essa segunda edição por volta de julho-agosto de 1931, em vista da relação de obras publicadas constante na última folha. ${ }^{3}$

Essas duas primeiras publicações da Bibliotheca, Konovaloff e Os inimigos, de 1930, já indicavam a tendência de lançamentos bimestrais. Quanto ao terceiro volume da coleção, não tenho certeza se saiu no final de 1930 ou em janeiro de 1931.

\footnotetext{
${ }^{3}$ Quanto à provável reimpressão dessa segunda edição, situo-a por volta de novembro de 1931, não só por causa da inclusão de mais um título na relação das obras publicadas pela casa, mas também por já estar operando em seu novo endereço, à Rua 15 de Novembro, 32, igualmente no centro de São Paulo.
} 
Trata-se de $O$ pavilhão no. 6, mais uma coletânea de Tchecoff, agora com cinco contos. A partir deste volume, a editora deixa de reproduzir a decantada mensagem de Guilherme de Almeida e some a introdução "À guisa de introito". Por outro lado, introduz-se o uso de vinhetas e ilustrações, a cargo de "M. [Miguel] Barychnicoff" (não excluo que fosse um pseudônimo), o qual continuará a colaborar em algumas outras obras da coleção. A foto de Tchecoff que aparecia em Os inimigos foi substituída por um desenho a bico de pena feito pelo referido ilustrador. Após a mesma introdução à vida e obra do autor que havia em Os inimigos, segue-se uma pequena prancha com uma foto de Wladimir Korolenko e dois parágrafos seus comentando $O$ pavilhão no. 6. De fato, uma bela ediçãozinha!

Há outras duas novidades neste volume. A primeira delas é a inclusão na segunda capa de uma listagem das obras no prelo. É uma listagem significativa não só por mostrar a linha editorial programada para a casa, mas também por nos permitir acompanhar a evolução e vicissitudes de seu catálogo. Por ora, são-nos prometidos seis lançamentos, dos quais veio a se concretizar apenas a primeira metade. ${ }^{4}$

A segunda novidade, até sensacional em vista da linha programática da casa, é o anúncio, na última página do livro, sobre a decisão da editora em criar uma nova coleção, "Obras Scientificas", concentrada nos trabalhos do médico e fisiologista Alexandre Lipschütz. Voltarei adiante ao tema.

Mas, do ponto de vista da trajetória da Edição Cultura, o que há de mais marcante neste terceiro lançamento da Bibliotheca de Auctores Russos é o fato de encerrar o ciclo da sociedade G. Selzoff \& F. Olandim.

Aqui quero comentar um aspecto em paralelo, a saber, o partido visual adotado nas capas. A edição de Konovaloff que tenho em mãos, restaurada e encadernada, não traz a capa da brochura original e, portanto, baseio-me nos dois títulos seguintes e num indício indireto. Como se pode ver nas imagens abaixo, a identidade visual é bastante clara e definida, com elementos do art déco então dominante, numa adaptação da fonte Broadway para os títulos, com fios verdes delimitando as áreas internas e o contorno da capa. Não deixava de indicar alguma pretensão de relativa elegância e

\footnotetext{
${ }^{4}$ São eles Khadji Murat e $O$ padre Sergio, de Tolstoi, O jogador, de Dostoievski, $O$ primeiro amor e Paes e filhos, de Turguenieff, e Dubrovski, de Puchki [sic].
} 
contemporaneidade. Como veremos mais adiante, essa unidade visual ${ }^{5}$ também desaparecerá com o fim da sociedade Selzoff/Olandim.

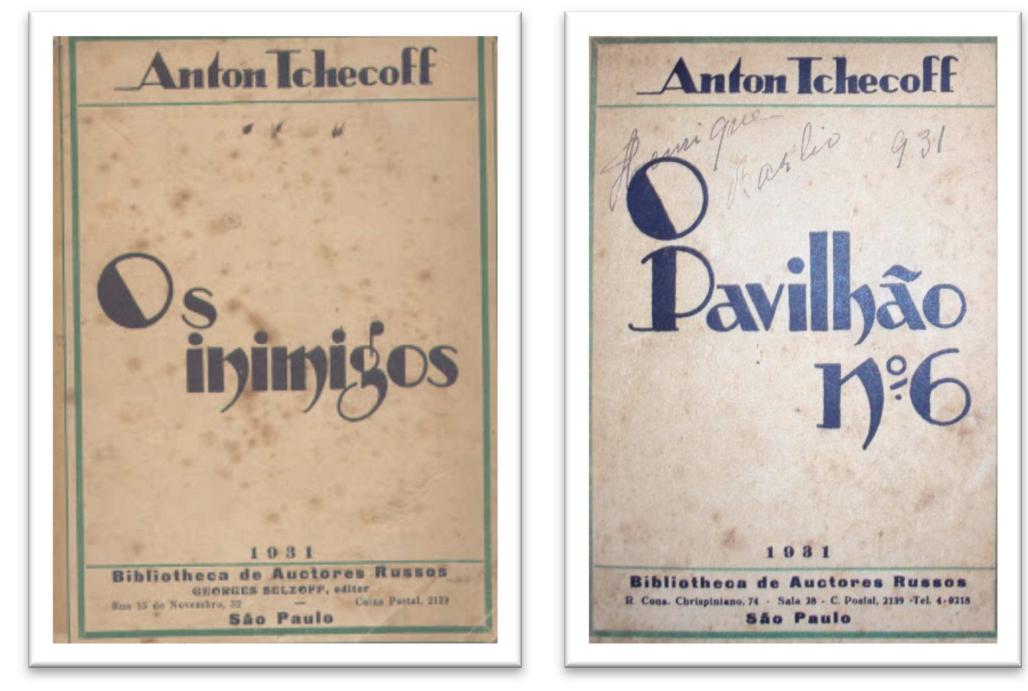

Identidade visual das capas

Uma palavra final sobre a participação de Olandim na editora, além de sua parceria no texto em português e talvez com um dedinho no partido visual de apresentação das obras: se era aquele mesmo Francisco Olandim amigo de Affonso Schmidt, se foi por meio dele que possivelmente se deu o contato com Guilherme de Almeida, se apenas as duas primeiras publicações da casa chegaram a se esgotar, não teria ele desempenhado também um papel não insignificante para a receptividade das obras publicadas na época em que era sócio da casa?

Seja como for, a partir de janeiro ou fevereiro de 1931 a Edição Cultura fica sob a égide exclusiva de Selzoff.

\section{A segunda fase}

Os quatro títulos seguintes são, por ordem de publicação: Khadji Murat e Padre Sergio, ambos de Leon Tolstoi, Um jogador (das notas de um rapaz). Igrok, de Feodor Dostoievski, e Judas Iscariotes, de Leonide Andreieff.

Quanto ao colaborador que teve Selzoff na tradução dessas obras, dispomos apenas de algumas referências indiretas.

\footnotetext{
5 A qual projeto hipoteticamente, e apenas em parte, também para Konovaloff, em vista de um anúncio publicado em $O$ bibliógrafo, cf. reprodução em Gomide (2004, p. 449).
} 
Segundo Eduardo Martins (1971, p. 31-2), teria sido Allyrio Meira Wanderley, de Patos da Paraíba, estabelecido em São Paulo desde 1924, a traduzir as três primeiras obras para a Bibliotheca da Selzoff. José Ozildo dos Santos (2011) acrescenta também a tradução de Judas Iscariotes. ${ }^{6}$ De acordo com o costume da casa, nenhum desses títulos traz créditos de tradução, e infelizmente nem Martins nem Santos especificam as fontes de onde extraíram as informações. Contudo, por vagas que sejam tais indicações, parecem-me ter um fundo de verdade, por uma razão que exporei mais adiante, e vou tomá-las por válidas.

Quanto à descrição desses volumes, temos vários elementos em comum: em todos eles consta "Edição Cultura - Georges Selzoff" e "Bibliotheca de Auctores Russos - Georges Selzoff' (e, depois de Khadji, acrescido Editor); a mensagem de Guilherme de Almeida citando Olandim desapareceu definitivamente e o mesmo se deu com as páginas "À guisa de introito".

Judas Iscariotes apresenta um novo elemento interessante: na página de rosto, sob o título da obra, consta " 1 ". Milheiro", dado até então inédito e que será retomado apenas numa obra posterior, Os sete enforcados, pertencente ao que considero a terceira e última fase da editora e da qual falarei no momento oportuno. Ademais, temos a impressão de um grande otimismo editorial ao ver a relação de obras então no prelo, estampada na última página do volume, com nada menos que dezesseis títulos, inclusive um cartapácio como Oblomoff, de Ivan Gontcharoff.

Nessa fase, é possível notar paralelamente uma perda de rumo e definição na forma de apresentação das obras. Khadji-Murat ainda tenta preservar elementos art déco, mas visivelmente afrouxados. Basta ver a inédita adoção do itálico para o nome do autor e um serifamento do "i" estranho às fontes usadas nos volumes anteriores. Em Padre Sergio, porém, fica visível o abandono de qualquer tentativa de coerência visual.

\footnotetext{
${ }^{6}$ Aqui aparece um daqueles problemas praticamente insolúveis: Martins (1971, pp. 31-32) apresenta com grande precisão os dados bibliográficos sobre as três edições cuja tradução teria sido de lavra de Wanderley, inclusive com centimetragem e número de páginas de cada volume, o que parece indicar que os teve nas mãos, provavelmente dentre o acervo de Wanderley. Por outro lado, Dainis Karepovs, sóbrio e meticuloso historiador da esquerda brasileira, em comunicação pessoal assegura definitivamente que Fúlvio Abramo lhe referiu ter traduzido uma obra para Selzoff. Sente-se uma vontade imensa de que tivesse sido Judas, pois preencheria tão bem a lacuna! Mas é algo que não podemos fazer - o fundamental é que fique registrada essa preciosa informação. Sobre Fúlvio Abramo tradutor, ver BOTTMANN, D. Uma vinheta. Traduzires vol. 1, n. 2 (UnB, dez. 2012): 33-35.
} 

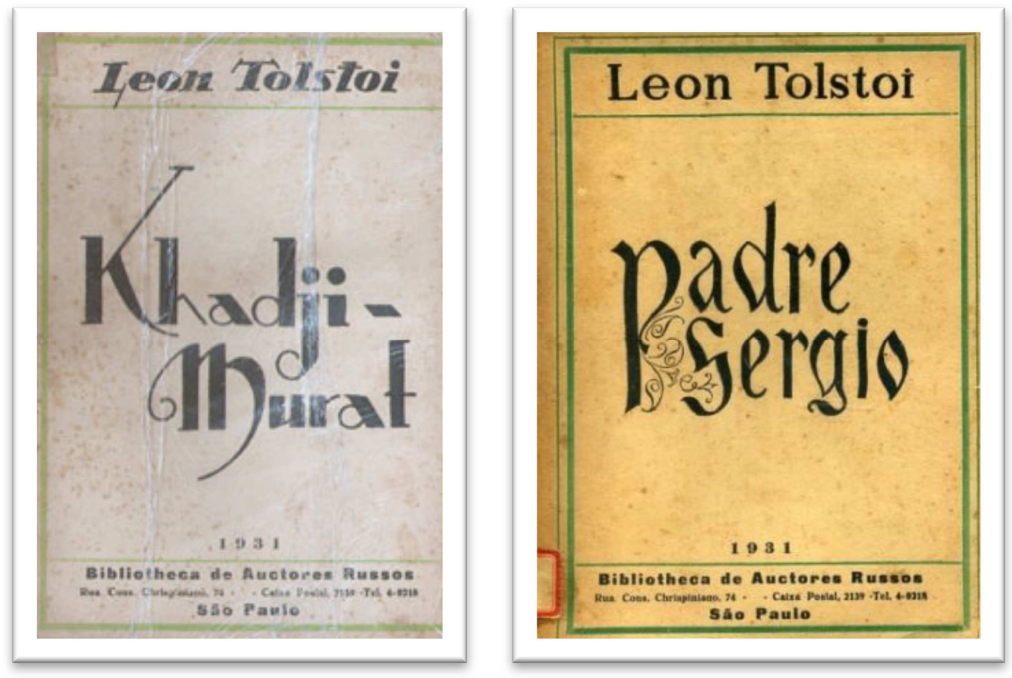

Afrouxamento da identidade visual das capas

A partir daí, seguimos ladeira abaixo, com duas capas francamente toscas em $O$ jogador e Judas Iscariotes, de criação do xará do célebre bailarino:
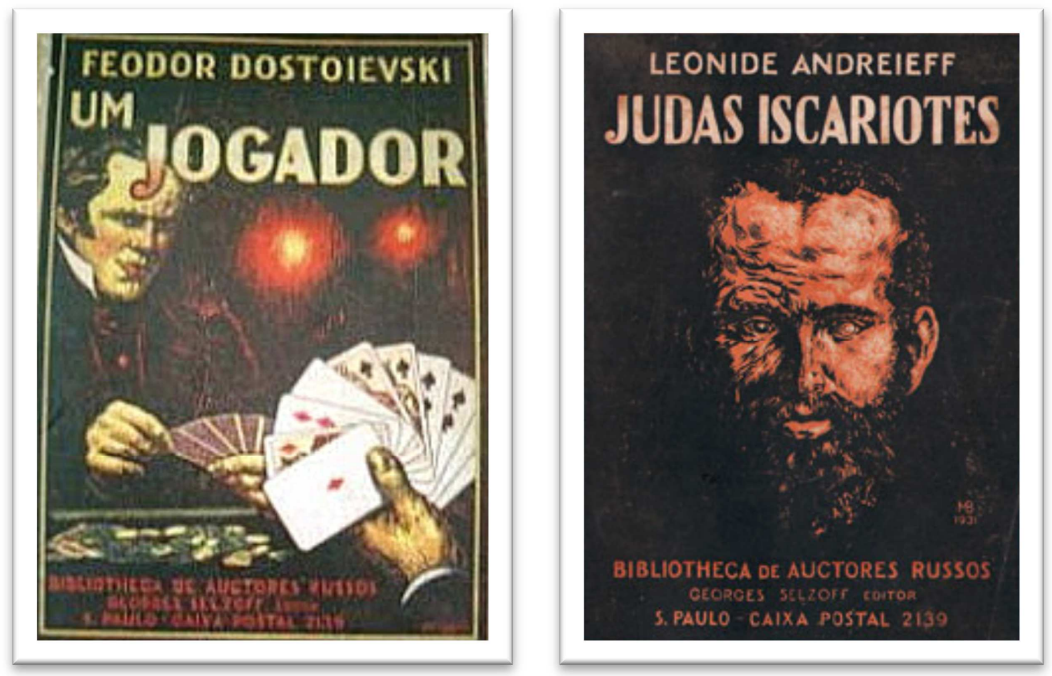

Nova identidade visual das capas

Tal volatilidade sugere irresistivelmente que, mesmo na parte gráfica, a editora estava às voltas com capistas, eles também, apenas eventuais. Tampouco o oculto novo parceiro de tradução, Allyrio Meira Wanderley, mantém por muito tempo sua contribuição, encerrando-a depois de seis ou oito meses. Quanto à colaboração de Fúlvio Abramo indicada à nota 6, terá sido ainda mais meteórica. 
Assim transcorreu o ano de 1931, ao cabo do qual o catálogo da Bibliotheca contava com sete ou quiçá oito volumes, entre contos, novelas e romances, de cinco autores, quais sejam, Gorki, Tchecoff, Tolstoi, Dostoievski e Andreieff.

\section{A divulgação}

Não que todo esse empenho tenha recebido grande atenção. Se a editora prometia a seus leitores uma extensa e variada programação de novos lançamentos, parecia, porém, cercada pelo entorpecido silêncio de sua quase nula divulgação. Vejamos o apanhado do que saiu na imprensa sobre ela.

A despeito dos votos calorosos de um imortal, a Edição Cultura só veio a merecer a atenção da imprensa cerca de seis meses depois de estrear seu catálogo. E isso nem em São Paulo, e sim no Rio de Janeiro, provavelmente graças aos bons préstimos do "Agente Exclusivo", sediado à Rua do Ouvidor, 160, 3. andar, que ainda na época da sociedade Selzoff/Olandim ficara incumbido de representar a editora na capital do país.

Mas é apenas em 27 de março de 1931 que teremos no Diário da Manhã uma breve notícia sobre a anterior criação da editora e o atual lançamento de Khadji-Murat. Transcrevo a nota, de título "Um livro de Tolstoi":

Foi creada, em S. Paulo, a Bibliotheca dos Autores Russos, destinada á divulgação, entre nós, da literatura slava, atravez de traducções das melhores obras dos grandes escriptores moscovitas. A Bibliotheca já editou livros de Gorki e Tchehoff, e agora acaba de lançar no mercado uma bella traducção de um dos livros mais fortes de Tolstoi - "Khadji Murat" - ou seja o "Diabo Branco" que aqui já foi levado em fita cinematographica e que é um romance notavel.

Feita por Selsoff, a traducção conserva todos os coloridos que o grande evangelisador do espirito russo sabia emprestar aos seus escriptos.

Como o lançamento de Khadji-Murat foi posterior à dissolução da sociedade, já sabíamos que se encerrara a participação de Olandim no trabalho de tradução. O novo colaborador, porém, fica à sombra e a tradução agora é apresentada como de lavra exclusiva de Selzoff.

Outra notícia da editora teremos apenas cinco meses depois, em agosto de 1931, decorrido praticamente um ano desde sua criação. Trata-se de um veículo também 
carioca, $O$ Bibliógrafo, boletim de não grande expressão dedicado a notícias bibliográficas. Transcrevo a nota, chamada "O sr. G. Selzoff e o intercâmbio intelectual brasileiro" (Gomide, 2004, p. 410, que atualizou a grafia):

Os nossos leitores já devem ter conhecimento da grande obra que está realizando o sr. Georges Selzoff, editor da Biblioteca dos Autores Russos, no sentido de alargar o intercâmbio intelectual russo-brasileiro. Assim, este editor já traduziu, de acordo com os respectivos originais, para o português, as obras mais notáveis da literatura russa, sobretudo as de Maximos Georki (sic), Anton, (sic) Tchecoft (sic), Dostoievski, Gogol.

O editor da Biblioteca de Autores Russos pretende ainda editar as obras de todos os grandes escritores russos antigos e modernos, tendo em vista a grande saída que as suas edições têm conseguido, devido ao cuidado com que são feitas as respectivas traduções e ao esmero que o sr. Selzoff põe em todos os trabalhos que a sua casa editora tem publicado. Com isso vem prestando a Biblioteca de Autores Russos um grande serviço à cultura de nosso país, intensificando a propaganda de obras tão interessantes.

A nota é um pouco ambígua: Gogol até podia já estar traduzido por Selzoff, mas nunca foi publicado pela editora, embora Tarass Bulba e, mais tarde, Almas mortas comparecessem na programação anunciada pela casa. Isso nos reforça a impressão de que bastava a Selzoff contar com uma primeira versão, um rascunho inicial de suas traduções, para vir a divulgá-las como obras no prelo - como se tudo estivesse praticamente pronto, só faltando publicar.

O Bibliógrafo também apresenta um breve informe com as "Edições a sair" e, em setembro do mesmo ano, uma "Bibliografia" de literatura russa, onde constavam alguns títulos da editora (Gomide, idem, ibidem).

Seis meses depois, em fevereiro de 1932, ainda o mesmo boletim publica uma resenha de Judas Iscariotes (Gomide, idem, p. 668), lançado cerca de cinco meses antes.

Se houve na época mais notícias sobre a Edição Cultura e sua Bibliotheca de Auctores Russos, não as localizei.

\section{Perspectivas}

Detenhamo-nos agora em alguns dados práticos e no quadro geral da época.

O preço de capa de cada brochura da Bibliotheca era de $5 \$ 000$, cinco mil-réis. Se tomarmos como base a relação 1 réu = 0,0056 de real, para o valor do réu em 1940, teríamos algo na faixa de 28 reais o exemplar. Em vista do índice médio de inflação na 
década de 1930, ainda por cima com tantos cataclismos no Brasil e no mundo, esse cálculo é meramente aproximativo e, com toda probabilidade, o valor de época seria não pouco mais alto.

Sobre o volume das tiragens, vimos que Judas Iscariotes, em sua página de rosto, traz especificado “ $1{ }^{\circ}$. Milheiro". Não sei se todas as tiragens atingiam um milhar de exemplares cada, mas, mesmo supondo que assim fosse, não creio que alguma delas tenha sido superior a esse número. Como vimos, a editora não dispunha de um esquema eficiente de distribuição e tinha carência de maior divulgação de seus lançamentos.

Acima de tudo, os primeiros anos da década de 1930 estavam sofrendo o brutal impacto da crise de 1929, gerando agudos desequilíbrios em toda a economia internacional e nacional. Além disso, naqueles anos vivia-se a recente implantação da ditadura varguista e em 1932, em São Paulo, trepidava-se sob a intervenção do governo federal, numa comoção que, a partir de julho daquele ano, veio a desencadear a chamada Revolução Constitucionalista. Foi um período que muito afetou também os negócios do mundo do livro, chegando a paralisar por algum tempo as atividades editoriais de outras empresas do ramo.

Em suma, o projeto podia parecer promissor, a disposição de trabalho podia ser grande, mas a conjuntura política e econômica não podia ser mais desfavorável. Em tal quadro, eram bastante incertos os rumos para uma pequeníssima editora, sem experiência na área, sem grande capital, dependendo da boa vontade de jovens escribas para colocar a tradução em bom português, dos votos auspiciosos de algum imortal da ABL, de breves notas em algum periódico aqui e ali.

Mas retomemos seu percurso.

\section{A terceira e última fase}

Após o malogro da sociedade com Olandim, após o término das ocultas colaborações de Allyrio M. Wanderley e Fúlvio Abramo, Selzoff parece ter alterado radicalmente sua estratégia para suas parcerias tradutórias.

Agora passa a contar com a colaboração de escritores ainda jovens, mas não totalmente desconhecidos, e a casa começa a creditá-los na página de rosto dos livros.

No final de 1931 ou, no máximo, em janeiro de 1932, a Bibliotheca de Auctores Russos lança um volume de Leonide Andreieff, Os sete enforcados. Agora temos lá que 
se trata de uma "traducção integral do original russo por Georges Selzoff e Orígenes Lessa". 7

É a única outra obra, além de Judas, que especifica sua tiragem.

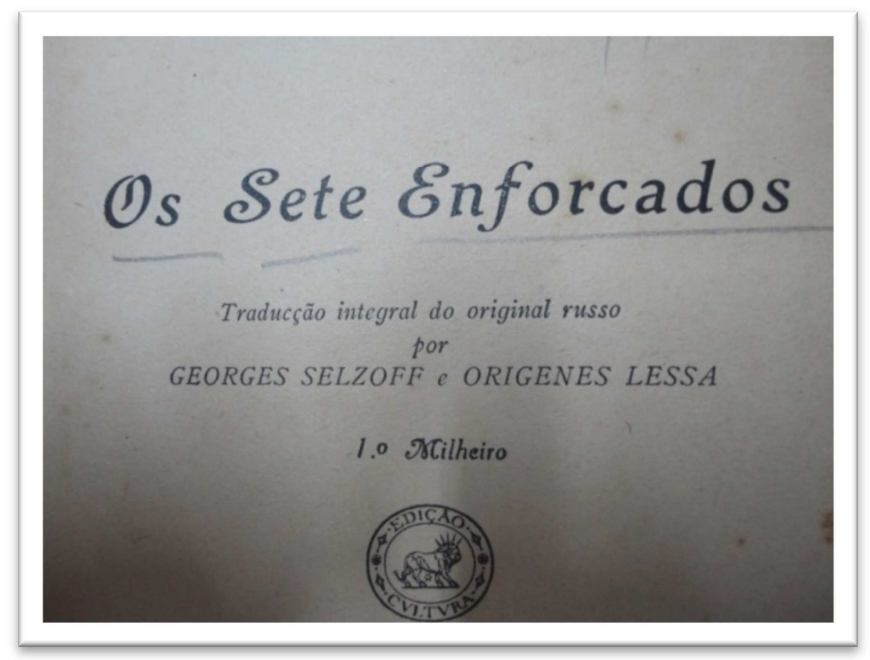

Créditos de tradução; tiragem

Esse volume apresenta um detalhe interessante. Se em Judas, ainda na fase de total ocultamento dos colaboradores, anunciava-se uma programação bastante extensa abrangendo dezesseis títulos, como vimos -, agora, no início dessas relações tradutórias estabelecidas em outras termos, a programação se enxuga à metade disso.

\footnotetext{
${ }^{7}$ Faço aqui um pequeno reparo à afirmação de Gomide (2004, p. 409) de que Lessa teria feito essa tradução ao sair do presídio onde, no segundo semestre de 1932, estivera por sua participação na Revolução Constitucionalista. Na verdade, a tradução foi feita em 1931, e o livro foi lançado muito provavelmente em dezembro do mesmo ano, no mais tardar em janeiro de 1932.
} 


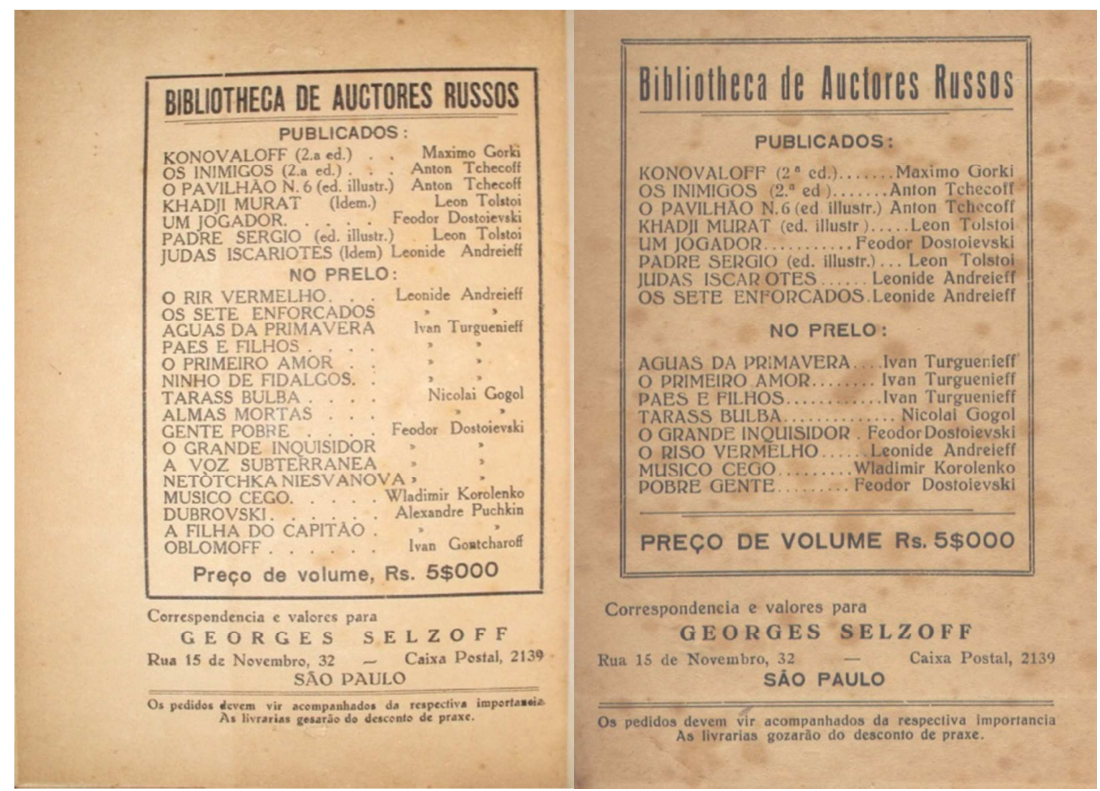

Listagens de obras no prelo, transição da segunda para a terceira fase (1931-32)

Todavia, mesmo com uma programação de lançamentos mais modesta, apenas duas dessas obras anunciadas chegam a vir à luz do dia.

Em fevereiro de 1932 sai o volume Ninho de fidalgos. Na página de rosto, a menção: “Traducção integral do original russo por Elsie Lessa e Georges Selzoff”.

Aqui, um primeiro detalhe. Embora $O$ Bibliógrafo já divulgasse desde setembro de 1931 o lançamento futuro de Ninho de gentilhomens (Gomide, 2004, p. 410) e Ninho de fidalgos constasse na programação estendida anunciada em Judas, essa tradução de Selzoff - finalmente publicada com a colaboração da jovem esposa de Orígenes Lessa, então na flor de seus vinte anos - não constava da listagem enxuta publicada em Os sete enforcados. Mas é justamente ela que, dois meses depois, segue-se ao romance de Andreieff. ${ }^{8}$

O segundo detalhe é que o Ninho volta a estampar a listagem estendida de obras no prelo, tal como em Judas, agora com catorze títulos (já que dois dos anunciados, justamente, vinham de ser lançados). Fica-se com a impressão de que a empresa, de alguma maneira, recuperara seu voluntarismo anterior, temporariamente abalado pela perda do anônimo colaborador, agora restaurado pela esperança de uma nova dinâmica um pouco mais permanente, e voltava a apostar vigorosamente em seu futuro.

\footnotetext{
${ }^{8}$ É esse tipo de ocorrência, entre outros indícios, que me leva a crer que Selzoff já dispunha de um estoquezinho de traduções suas numa versão inicial, e que o lançamento delas dependia basicamente dos préstimos de um terceiro para burilar o texto. Ver nota 1.
} 
Mas, dois meses depois, temos o canto do cisne. Em abril de 1932, é lançado o derradeiro livro da casa: Águas da primavera, também de Turguenieff, em “Traducção integral do original russo por Brito Broca e Georges Selzoff”.

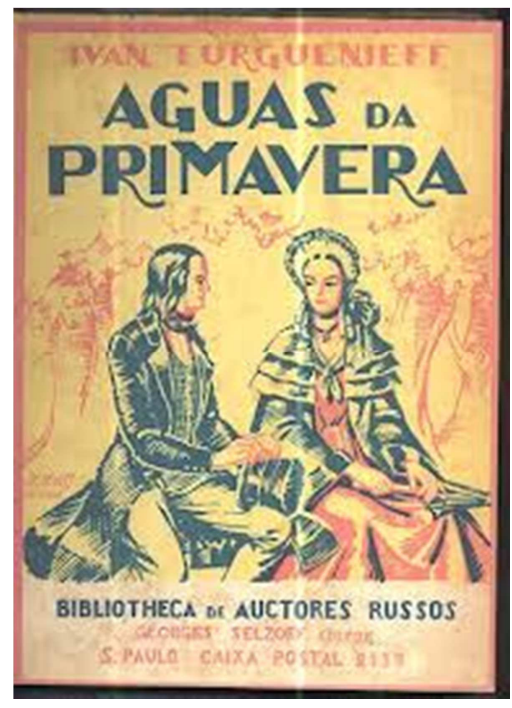

Última obra publicada pela Edição Cultura

Depois disso, nada mais. E assim, após seguir um acidentado curso por cerca de vinte meses, finda a trajetória da Bibliotheca de Auctores Russos. Seu saldo: dez volumes e seis autores, agora acrescido Turguenieff.

\section{O catálogo da Bibliotheca}

Pela reconstituição que pude fazer, os livros publicados na coleção russa foram os seguintes, por ordem cronológica de lançamento: ${ }^{9}$

- Maximo Gorki, Konovaloff, contendo "Konovaloff", "A feira”, "Kirilka" e "Uma vez, no outomno". [Tradução com F. Olandim.] 1930. 156 p. 2a . edição revista em 1931.

- Anton Tchecoff, Os inimigos, contendo "Os inimigos", "Delírio (Gussieff)", "Algazarra em família", "No carro (O caminho da mestra escola)", "Verotchka", "Estudante", "Lenda sueca (O conto do jardineiro chefe)", "Zinotchka" e "Uma noite atroz". [Tradução com F. Olandim.] 1930. 178 p. 2ª . edição revista em 1931.

\footnotetext{
${ }^{9}$ Deixei entre colchetes os créditos de tradução nos casos em que a atribuição se deu por inferência. Nos demais, reproduzi os créditos conforme constam na página de rosto das obras.
} 
- Anton Tchecoff, O pavilhão no. 6, contendo "O pavilhão no. 6", "A desgraça”, "A felicidade", "A obra de arte" e "Os simuladores". [Tradução com F. Olandim.] 1930[1]. Vinhetas e illustrações de M. Barychnikoff. 187 p.

- Leon Tolstoi, Khadji-Murat. [Tradução com Allyrio Meira Wanderley.]. Obra Posthuma, Versão Integral. 1931. Vinhetas e illustrações de M. Barychnikoff. $173 \mathrm{p}$.

- Leon Tolstoi, Padre Sergio. [Tradução com Allyrio Meira Wanderley.] Vinhetas e illustrações de M. Barychnikoff. 1931. 176 p.

- Feodor Dostoievski, Um jogador (das notas de um rapaz). Igrok. [Tradução com Allyrio Meira Wanderley.] 1931. 170 p.

- Leonide Andreieff, Judas Iscariotes. [Tradução com Allyrio Meira Wanderley (Fúlvio Abramo? Ver nota 6).] Illustrações de M. Barychnikoff. 1931. 141 p.

- Leonide Andreieff, Os sete enforcados. Traducção integral do original russo por Georges Selzoff e Orígenes Lessa. 1931[2]. 150 p.

- Ivan Turguenieff, Ninho de fidalgos. Traducção integral do original russo por Elsie Lessa e Georges Selzoff. Imagem de Turguenieff por Miguel Barychnicoff. No testo 5 illustrações e vinhetas, em nankin, feitas especialmente para esta edição, por Inne Zueff (Milão). 1932. 184 p.

- Ivan Turguenieff, Águas da primavera. Traducção integral do original russo por Brito Broca e Georges Selzoff. 1932. 201 p.

\section{A sinérgica coleção "Autores Brasileiros Modernos"}

Paralelamente à Bibliotheca de Auctores Russos, no segundo semestre de 1931 a Edição Cultura deu início a outra coleção, Autores Brasileiros Modernos, que afinal publicou tão-só duas obras.

São de autoria de dois colaboradores da casa, Allyrio Meira Wanderley e Orígenes Lessa. Quanto ao primeiro, assinando apenas como Wanderley, temos Sol criminoso, romance que mantivera guardado em sua gaveta por alguns anos, até sair em 1931. Do segundo, temos o volume de contos A cidade que o diabo esqueceu, lançado em janeiro de 1932 e que recebeu na época breve nota no Diário Nacional.

Era a isso que eu me referia mais acima, ao afirmar que, por vagas que fossem as indicações disponíveis, parecia efetivamente plausível a participação de Allyrio Meira 
Wanderley na tradução de algumas das obras da Bibliotheca. Pois, diante desses dois livros publicados pela casa, o de Wanderley e o de Lessa, é inescapável a impressão de uma espécie de "sinergia" entre Selzoff no papel de editor e seus parceiros de tradução.

\section{A malograda coleção "Obras Scientificas"}

Ainda a respeito dessas mútuas gentilezas, por assim dizer, há um pequeno episódio interessante. Para situá-lo, retomo o tema deixado em suspenso a respeito de outra coleção da casa, afinal nunca concretizada, a já referida "Obras Scientificas".

O caso foi o seguinte: em setembro de 1930, o médico e fisiologista Alexandre Lipschütz, de Riga, na Letônia, estivera no Brasil, onde estabeleceu contato com seu quase conterrâneo Zéltzov. Conta Lipschütz (1933, p. 9) que "o sr. Georges Selzoff ofereceu-se amavelmente para lançar uma edição brasileira" de Warum wir sterben, com o que "Concordei com o maior prazer". Assim Selzoff, que mal acabara de publicar o primeiro livro na recém-criada editora, obteve os direitos de publicação da obra de Lipschütz. No começo de 1931, chegou a anunciar que a obra já estava no prelo, com o título de Porque morremos. Até o encerramento da editora em abril de 1932, porém, ela continuou inédita e a coleção "Obras Scientificas" nunca tomou forma.

Afinal, foi a Companhia Editora Nacional que publicou o livro em 1933, em sua Bibliotheca Pedagógica Brasileira. A tradução? Feita a quatro mãos por Georges Selzoff e, ainda, Allyrio Meira Wanderley (fazendo-se constar apenas como A. Meira). Visto que Orígenes Lessa acabava de ter publicados dois livros seus pela Nacional, não parece implausível supor que tenha sido ele a intermediar os contatos entre seu ex-editor e seu então editor, para viabilizar a edição da obra cujos direitos de publicação Lipschütz cedera a Selzoff.

\section{Excurso}

O encerramento das atividades da Edição Cultura não significava necessariamente o fim de seus estoques. Assim é que, em 1934, temos notícias de uma firma chamada A. Meira, Editor, anunciando a venda de Sol criminoso, de Wanderley (como vimos, A. Meira e Wanderley eram ambos o mesmo Allyrio Meira Wanderley).

Ainda em 1934, no processo de falência da editora Unitas, Georges Selzoff consta como pessoa física entre os credores arrolados em cartório, com um crédito em aberto de 2 mil contos de réis. Uma hipótese plausível, aventada por Dainis Karepovs, é 
que este valor correspondesse a obras deixadas em consignação à Unitas, que operava também como agente de contato para a distribuição de várias editoras, do Rio e de São Paulo.

\section{Fortuna histórica}

A fortuna posterior de tais traduções consistiu em grande parte num processo de apagamento.

Consta da biografia de Brito Broca a feitura da tradução de Águas da primavera e de Primeiro amor - este último anunciado, porém jamais publicado pela Bibliotheca de Auctores Russos. ${ }^{10}$ Mas, mesmo em relação a Águas da primavera, não há menção a Selzoff, seja como editor, seja como parceiro tradutor.

Analogamente, a tradução de Ninho de fidalgos é lembrada em nossos anais somente por Nelly Novaes Coelho (2003, p. 190), e mesmo assim muito de passagem, em seu verbete sobre Elsie Lessa, sem qualquer menção a Selzoff.

O mesmo ocorre nos materiais sobre Allyrio Meira Wanderley, referentes a suas três (Martins) ou quatro (Santos) traduções publicadas pela casa.

Quanto a Fúlvio Abramo, foi sua própria participação que praticamente desapareceu de qualquer fonte escrita.

Em relação a Orígenes Lessa, o caso é um pouco mais intrincado. Na antologia Os russos: antigos e modernos, organizada por Rubem Braga e publicada em 1944 pela Editora Leitura em sua coleção "Contos do Mundo", a tradução de Os sete enforcados vem atribuída exclusivamente a Lessa. A coletânea organizada por Rubem Braga tem vida longa, retomada pela Ediouro em O livro de ouro dos contos russos nos anos 70 e depois, em 2004, com o título de Contos russos: os clássicos.

Braga (2004, p. 9) se limita a comentar sucintamente no prefácio à antologia: “[...] alegro-me pelo fato de poder apresentar em tradução direta do russo duas obrasprimas: 'O capote' e 'Os sete enforcados'. Ambos foram traduzidos por escritores brasileiros em colaboração com sabedores de russo", sem a mais remota indicação sobre as edições anteriores ou a identidade desses "sabedores de russo".

Destino ainda mais triste teve Os sete enforcados no sétimo volume da Coleção "Grandes Romances Universais”, da W. M. Jackson, com várias reedições a partir de

\footnotetext{
${ }^{10}$ A novela sai traduzida por Brito Broca em 1949, pela José Olympio. Ignoro se chegara a ser feita ou mesmo iniciada em parceria com Selzoff nos idos de 1932.
} 
1947 até 1963. Não consta qualquer informação sobre a autoria da tradução, nem sobre a origem editorial do texto. $\mathrm{O}$ verso da página de rosto traz apenas "Tradução revista e adaptada para esta Coleção pelo Departamento Editorial de W. M. Jackson Inc.”.

No mesmo volume da mesma coleção da W. M. Jackson, não muito melhor destino teve Khadji-Murat, também apresentado em "Tradução revista e adaptada para esta Coleção pelo Departamento Editorial de W. M. Jackson Inc.”. Dentro do volume, acrescentou-se ao título um subtítulo entre parênteses: ( $O$ diabo branco). A bem da verdade, neste caso específico a própria Bibliotheca selzoffiana não contribuíra em nada para a identificação explícita dos tradutores. De todo modo, era hábito frequente da W. M. Jackson omitir não só a autoria das traduções, mas também as referências às editoras em que se socorria.

Além da apropriação pela W. M. Jackson, o Khadji-Murat da Bibliotheca de Auctores Russos conhecera, poucos anos antes, destino similar na Edições e Publicações Brasil Editora S/A, que relançou a tradução de Selzoff/Allyrio sem qualquer referência à edição de origem. $\mathrm{O}$ volume não traz data de publicação, mas calculo por volta de 1945. Na página de rosto consta apenas O diabo branco (Khadji Murat)-Obra Póstuma - Edição integral - Revista. ${ }^{11}$

Em vista do sistemático esquecimento dos créditos editoriais nessas publicações, tanto mais meritório é o procedimento adotado pela Melhoramentos. Em 1955, como nono volume de sua coleção "Novelas do Mundo", a editora publica Águas da primavera, de Turguenieff, fazendo constar na página de rosto "Tradução revista por Marina Stepanenko". Em seu verso tem-se a especificação: "Esta obra foi, inicialmente, publicada na Biblioteca de Autores Russos de Georges Selzoff, em tradução de Brito Broca e Georges Selzoff". 12

\footnotetext{
${ }^{11}$ Quanto a $O$ diabo branco, usado ora como título, ora como subtítulo, é um detalhe que, por si só, já renderia uma crônica inteira sobre a fortuna de Khadji-Murat no Brasil. A obra de Tolstói fora adaptada para o cinema por Alexandre Volkoff numa produção alemã em 1930, que se celebrizou em sua versão francesa como Le Diable blanc. Ao que parece, o romance causou um pequeno furor editorial no Brasil naquela época: nada menos que cinco edições diferentes em dezoito anos! Além da publicação na Bibliotheca de Auctores Russos em 1931, temos em 1934 O diabo branco [Khadji-Murat] pela Civilização Brasileira, em tradução do lusitano António Sérgio, muito provavelmente pelo francês; $O$ diabo branco pela Edições e Publicações Brasil em $c$. 1945, anônima e tomada à Bibliotheca de Selzoff; Khadji Murat (o diabo branco), na edição da W. M. Jackson em 1947, igualmente anônima e tomada à Bibliotheca, como vimos; $O$ diabo branco pela Vecchi, em tradução direta de Boris Schnaiderman assinando como Boris Solomonov, em 1949.

${ }^{12}$ A edição da Melhoramentos chega a preservar em epígrafe a lucreciana divisa da Edição Cultura, Eripitur persona, manet res, talvez por crer que fizesse parte da novela de Turguenieff.
} 
Mesmo em nossos acervos disponíveis na Biblioteca Nacional, é esgarçada a presença das publicações da Bibliotheca de Auctores Russos. Lá encontramos apenas metade delas: Konovaloff, O pavilhão n. 6, Khadji-Murat, Judas Iscariotes, Ninho de fidalgos e só.

Quanto ao mais, a pesquisadores e bibliófilos resta apenas o tortuoso e amiúde infrutífero recurso a sebos.

Concluindo, fica o apelo: que alguma instituição proceda com urgência à digitalização das obras publicadas pela pioneiríssima Bibliotheca de Auctores Russos, do tradutor-editor Georges Selzoff, antes que seus últimos vestígios acabem de se perder por completo.

\section{Referências}

\section{Fontes primárias}

Biblioteca Nacional, Acervo Geral, Catálogo Antigo

Biblioteca Nacional, Hemeroteca Digital Brasileira, jornais de São Paulo e Rio de Janeiro, 1930-1939

\section{Fontes secundárias}

BRAGA, R. (Org.). Contos russos: os clássicos. Prefácio [1944]. Rio de Janeiro: Ediouro, 2004.

COELHO, N. N. Dicionário crítico de escritoras brasileiras. São Paulo: Escrituras, 2002.

GOMIDE, B. B. Da estepe à caatinga: o romance russo no Brasil (1887-1936). São Paulo: EDUSP, 2012. Citado aqui na versão inicial da tese de doutorado, IEL/ UNICAMP, 2004.

LIPSCHÜTZ, A. Introducção do autor á edição brasileira. Porque morremos. Tradução A. Meira e G. Selzoff. São Paulo: Companhia Editora Nacional, 1933. MARTINS, E. Allyrio Meira Wanderley - cadeira n. 37. João Pessoa: Academia Paraibana de Letras, 1971. 
MEDEIROS, G. Entrevista com Boris Solomônovitch Schnaiderman. Revista USP, n. 75, set./nov. 2007. Disponível em: http://www.usp.br/revistausp/75/09gutemberg.pdf.

SANTOS, J. O. Allyrio Meira Wanderley: um perfil de corpo inteiro. Construindo a história. Disponível em: http://www.construindoahistoria.com/2011/10/allyriomeira-wanderley.html.

SCARPIN, P. Nossos três russos. Piauí, edição 47, ago. 2010. Disponível em: http://revistapiaui.estadao.com.br/edicao-47/questoes-literarias/nossos-tres-russos.

SELZOFF, G. À guisa de introito. In: GORKI, M. Konovaloff. São Paulo: Edição Cultura, 1930.

Correspondência pessoal com Dainis Karepovs, Gutemberg de Medeiros e José Mota Victor.

\section{Agradecimentos}

Para esta reconstituição, reuni e alinhavei informações dispersas entre várias fontes. Foram fundamentais as várias contribuições do historiador Dainis Karepovs, do jornalista e pesquisador Gutemberg de Medeiros e do historiador José Mota Victor. A eles, meus vivos agradecimentos. Ao crítico literário Alfredo Monte e a meu companheiro Federico Carotti, agradeço a paciente leitura. 